\title{
The Law and Sexual Harassment in the Physiotherapy Work Environment in South Africa
}

\begin{abstract}
This paper presents the legal framework within which sexual harassment of healthcare professionals, including physiotherapists, may be managed in their work environment in South Africa. According to both international and national legal principles, sexual harassment is considered a form of discrimination. There are various statutes in South Africa that may assist physiotherapists when they seek redress after being sexually harassed. These entail labour-related laws, laws aimed at removing all forms of discrimination, as well as the criminal and civil pathways of seeking justice.
\end{abstract}

KEY WORDS: SEXUAL HARASSMENT, MANAGEMENT, LAW, LEGAL PRINCIPLES, PHYSIOTHERAPY, HEALTHCARE.

\section{INTRODUCTION}

Three international studies (published in five articles) were conducted exclusively on sexual harassment of physiotherapists (or physiotherapy students) by patients (deMayo 1997, McComas et al 1993 and 1995, O'Sullivan and Weerakoon 1999 , Weerakoon and O'Sullivan 1998). Sexual harassment by other perpetrators were not examined. No studies have been published on sexual harassment of physiotherapists in South Africa.

Eighty-one percent $(81 \%)$ of the respondents to the McComas et al (1993) survey; $48.6 \%$ of the respondents to the deMayo (1997) survey and $37.5 \%$ of the respondents to the Weerakoon and O'Sullivan (1998) survey had been sexually harassed. The three studies concluded that physiotherapists in Canada (McComas et al 1993 and 1995), America (deMayo 1997) and Australia (O'Sullivan and Weerakoon 1999, Weerakoon and O'Sullivan 1998) require more information on ethical matters concerning sexual issues in the physiotherapy profession, as well as on the legal principles underlying the management of sexual harassment in the physiotherapy work environment. This would not only be relevant to sexual harassment by patients, but also by other perpetrators, since empirical studies conducted on nurses and nursing students
(Barnett 1996, Bronner et al 2003, Finnis and Robbins 1994, Hanrahan 1995, Libbus and Bowman 1994, Madison 1997), medical students (Koba 1995, Maida et al 2003, Margittai et al 1996, Moscarello et al 1996, Oancia et al 2000, Uhari et al 1994), medical practitioners (Cook et al 1995, McNamara et al 1995) have revealed that sexual harassment by colleagues and other healthcare professionals also occurs.

This paper therefore introduces the legal framework which serves as the basis on which sexual harassment should be handled in South Africa. The healthcare sector, and in specific the physiotherapy profession, must base any management of sexual harassment on sound legal principles.

\section{AIM OF THIS PAPER}

The core principles pertaining to the legal basis according to which sexual harassment should be managed in the work environment in South Africa (including the physiotherapy work environment) are discussed in the following paragraphs. Since these principles, as well as their practical application in the physiotherapy work environment are not well-known, educators have an important role to play in bringing this issue to the attention of both student and qualified physiotherapists.
Bütow-Dütoit L, PhD'; Eksteen CA, PhD'; De Waal M, D Litt et Phil ${ }^{2}$

1 Department of Physiotherapy, Faculty of Health Sciences, University of Pretoria.

${ }^{2}$ Former Director, Centre for Gender Studies, Department of Sociology, University of Pretoria.

\section{LEGAL PRICIPLES PERTAINING TO} SEXUAL HARASSMENT

Sexual harassment is not only considered an infringement of the victim's constitutional rights, but is also considered a form of gender discrimination and therefore equality discrimination, which is contrary to the principles of the Bill of Rights (The Constitution of the Republic of South Africa 1996). Furthermore, both international and national law sees any form of discrimination, including that based on gender, as illegal.

\section{International legal principles regard- ing sexual harassment}

In 1995, South Africa ratified the United Nations Convention on Elimination of All Forms of Discrimination Against Women (CEDAW) (n.d.). This means that the government must ensure that public authorities, institutions and individual persons do not discriminate against women. One of the forms of discrimination is gender-based violence.

\section{CORRESPONDENCE TO:}

L Bütow-Dütoit

P O Box 345

Wapadrand 0050

Tel: (012) 807-0814

Fax: (012) 807-3064 
CEDAW defines this as 'violence which is directed against a woman because she is a woman, or which affects women disproportionately; gender-based violence includes acts that inflict physical, mental, or sexual harm or suffering, threats of such acts, coercion, or other deprivations of liberty.' This definition further includes, but is not limited to: 'Physical, sexual and psychological violence occurring within the general community, including rape, sexual abuse, sexual harassment and intimidation at work, in education institutions and elsewhere, trafficking in women and forced prostitution' (Human Rights Watch 2001).

Sexual harassment is therefore clearly labelled a form of discrimination, both internationally, according to CEDAW (n.d.), the United States of America (USA) and England (Grogan 2001) as well as nationally, in South Africa. The South African perspectives on the legal principles pertaining to sexual harassment are included in the national legal principles.

\section{National Legal principles regarding sexual harassment}

Although the Promotion of Equality and Prevention of Discrimination Act (2000) does not supply a legal definition of sexual harassment, it includes a legal definition of generalised discrimination: '...any act or omission, including a policy, law, rule, practice, condition or situation which directly or indirectly (a) imposes burdens, obligations or disadvantages on; or (b) withholds benefits, opportunities or advantages from, any person on one or more of the prohibited grounds'.

The Employment Equity Act (1998) applies to all employers, regardless of whether they belong to the public or private sector: '...every employer must take steps to promote equal opportunity in the workplace by eliminating unfair discrimination in any employment policy or practice.' Furthermore, this Act instructs employers to inform employees of the provisions of the Act, including the information that sexual harassment is a form of discrimination, and it prohibits any further discrimination against employees who exercise their rights according to this Act. Specifically relevant to sexual harassment, the Act instructs employers to consult with the necessary parties and to eliminate conduct of employees which is contrary to the Act. If the employer does not do this, then he / she also exercises a form of discrimination and becomes liable for the actions of the relevant employee (harasser) (International Labour Organization 2001, Seminars tackle sexual harassment in the workplace 1998).

\section{The law and sexual harassment in the workplace}

Any management of sexual harassment in the healthcare setting should adhere to the Labour Relations Act (1995) which serves as the basis for the Guidelines and Codes of Practice (1998) (summarized in Table 1) for management of sexual harassment in the general employment sector. Table 1 therefore represents the practical application of national legal principles pertaining to sexual harassment in the work place. The most important aim of this code is the enhancement of 'respect (of) one another's integrity, dignity, privacy and the right of equity in the workplace.'

Employers should adopt disciplinary rules that establish the standard of conduct required of their employees (Labour Relations Act 1995). Employees should have neither any fear of reprisals should they lay a complaint, nor should they fear their complaints being ignored or trivialised. A non-employee may lodge a complaint of sexual harassment with the employer of the harasser if the offensive behaviour has taken place in the workplace or within the work environment (Guidelines and Codes of Practice 1998). Both employers and employees are responsible for discouraging sexual offensive behaviour in customers, job applicants and suppliers (Grogan 2001) although at present, it is illegal to take disciplinary steps (including in cases such as sexual harassment) against nonemployees (Labour Relations Act 1995). This means that employers of physiotherapists, or physiotherapists themselves, are unable to take disciplinary action against patients, and must find an alternative way to handle sexual harassment by a patient. An interesting concept is that even a private practice, run by a single healthcare professional (such as a physiotherapist), should have a predetermined complaint procedure set in place. This is not only an ethical obligation, but would also prevent the employed healthcare worker (or even patient, if relevant) from having to go elsewhere to lay a complaint (Dental Protection Ltd 1998/99). The issue of sexual harassment, however, must be taken a step further, as the complainant, if an employee, has the right to a more formal procedure (Table 1) for the handling of a complaint. Codes of Good Practice ( Code of Good Practice 2001) are not authoritative summaries of the law, and it is not a criminal offence to ignore them. However, when the courts / tribunals interpret or apply the relevant Acts during a hearing of a case, they must consider the Codes of Good Practice (Code of Good Practice 2001).

If a policy on sexual harassment is in place, it should therefore be made widely known to all employees and it should never exclude the possibility of the individual taking steps to pursue a criminal prosecution (Guidelines and Codes of Practice 1998, Robbins, Bender and Finnis 1997). Those who interfere with others wishing to make a complaint should also be disciplined (Guidelines and Codes of Practice 1998).

If the complainant of an allegation of sexual harassment in the workplace decides to choose the formal option of dealing with the complaint, the Labour Relations Act (1995) refers to the requirements surrounding the confidential formal disciplinary inquiry involving a complaint in the workplace (Labour Relations Act 1995), but it does not specifically describe how the investigation should proceed before this formal inquiry is held. However, the person who has been designated to investigate these complaints (Guidelines and Codes of Practice 1998), may follow the suggestions by Wagner (1992) and Lightle and Doucet (1992) on how to interview both the complainant and the alleged offender, as well as any prospective witnesses to the alleged incident. Following this initial investigation, a recommendation should be made to the employer or management of the organisation (Lightle and Doucet 1992). The recommendation is either that the investigation was inconclusive, that a written warning should be given to the offender (Lightle and Doucet 1992), or that a formal disciplinary inquiry should be held to determine whether the offender's conduct warrants a dismissal (Labour Relations Act 1995). Practical suggestions for this investiga- 
Table 1: Guidelines on how complaints of sexual harassment should be managed in the private physiotherapy practice.

GUIDELINES FOR MANAGEMENT OF SEXUAL HARASSMENT IN THE WORKPLACE

[compiled for this paper from: Guidelines and Codes of Practice (1998)]

\begin{tabular}{|c|c|c|c|}
\hline Procedure & Action & Reason & Details of procedure \\
\hline $\begin{array}{l}\text { 1. Advice \& } \\
\text { assistance for } \\
\text { complainant }\end{array}$ & $\begin{array}{l}\text { To approach designated } \\
\text { person outside line } \\
\text { management to hear } \\
\text { advice }\end{array}$ & $\begin{array}{l}\text { For confidential advice } \\
\text { on how to manage } \\
\text { situation }\end{array}$ & $\begin{array}{l}\text { a) person employed for this function } \\
\text { (amongst others) / trade union representative / } \\
\text { co-employee / outside professional; b) person } \\
\text { with appropriate skills / experience / training / } \\
\text { adequate resources to aid complainant; } \\
\text { c) this person may be required to have } \\
\text { counselling \& labour relations skills / to provide } \\
\text { confidential support \& advice }\end{array}$ \\
\hline $\begin{array}{l}\text { 2. Options for } \\
\text { resolving } \\
\text { situation }\end{array}$ & $\begin{array}{l}\text { Employees informed of } \\
\text { informal or formal options }\end{array}$ & $\begin{array}{l}\text { No duress exerted on } \\
\text { choice of option }\end{array}$ & $\begin{array}{l}\text { a) Informal procedure for resolving problem; } \\
\text { b) Formal procedure for resolving problem }\end{array}$ \\
\hline \multirow[t]{2}{*}{$\begin{array}{l}\text { 2.1. Informal } \\
\text { procedure }\end{array}$} & $\begin{array}{l}\text { Complainant to confront } \\
\text { person with unwanted } \\
\text { conduct }\end{array}$ & $\begin{array}{l}\text { This might be sufficient } \\
\text { for preventing further } \\
\text { harassment }\end{array}$ & $\begin{array}{l}\text { Complainant to explain to perpetrator: } \\
\text { a) behaviour not welcome; b) behaviour offensive; } \\
\text { c) behaviour makes him/her uncomfortable; } \\
\text { d) behaviour interferes with his/her work }\end{array}$ \\
\hline & $\begin{array}{l}\text { a) If informal procedure } \\
\text { is unsuccessful; } \\
\text { b) If case is severe; } \\
\text { c) If unwanted conduct } \\
\text { continues }\end{array}$ & $\begin{array}{l}\text { Then a formal, instead of } \\
\text { an informal procedure, } \\
\text { is another option }\end{array}$ & $\begin{array}{l}\text { Formal procedure, instead of informal procedure } \\
\text { to be used in severe cases: a) sexual assault; } \\
\text { b) rape; c) a strip search; d) 'quid pro quo' } \\
\text { harassment (victim has rights to pursue other } \\
\text { legal action too, such as criminal action } \\
\text { - refer to } 2.3 \text { in the table) }\end{array}$ \\
\hline $\begin{array}{l}\text { 2.2. Formal } \\
\text { procedure }\end{array}$ & $\begin{array}{l}\text { To be voluntarily chosen } \\
\text { by the complainant } \& \\
\text { not to be forced by } \\
\text { person to whom } \\
\text { complaint is made }\end{array}$ & $\begin{array}{l}\text { Method for carrying out } \\
\text { formal procedure must be } \\
\text { in place beforehand }\end{array}$ & $\begin{array}{l}\text { Procedure must specify: a) with whom the } \\
\text { grievance must be lodged; b) specify the time } \\
\text { frames for allowing the grievance to be dealt with; } \\
\text { c) provide that if the grievance is not resolved } \\
\text { satisfactorily, there are further actions available } \\
\text { (refer to CCMA) }\end{array}$ \\
\hline $\begin{array}{l}2.2 .1 \\
\text { Investigation } \\
\text { and } \\
\text { disciplinary } \\
\text { action after } \\
\text { formal } \\
\text { procedure }\end{array}$ & $\begin{array}{l}\text { To use guidelines found } \\
\text { in Schedule } 8 \text {. (of Act) } \\
\text { (not included here) }\end{array}$ & $\begin{array}{l}\text { Aggrieved party: not to be } \\
\text { disadvantaged; Other } \\
\text { party, if innocent: not to } \\
\text { be prejudiced }\end{array}$ & $\begin{array}{l}\text { a) dismissable offence - serious misconduct / } \\
\text { repeated incidents of sexual harassment / sexual } \\
\text { harassment still occurring after warnings; } \\
\text { b) handling of dismissable offences according to } \\
\text { guidelines in Act (Schedule 8)(not included here);* } \\
\text { c) range of disciplinary actions to be made known } \\
\text { beforehand; d) also a disciplinary offence to } \\
\text { retaliate against employee lodging a complaint of } \\
\text { sexual harassment in good faith }\end{array}$ \\
\hline $\begin{array}{l}2.2 .2 \\
\text { Resolution } \\
\text { of dispute }\end{array}$ & $\begin{array}{l}\text { If no satisfactory } \\
\text { resolution, then may refer } \\
\text { to CCMA for free service }\end{array}$ & $\begin{array}{l}\text { Referral for conciliation, } \\
\text { mediation and arbitration }\end{array}$ & $\begin{array}{l}\text { May refer to CCMA within } 30 \text { days of arising of } \\
\text { dispute; CCMA to use prescribed methods of } \\
\text { conciliation; If no CCMA conciliation, then may } \\
\text { refer to Labour Court within } 30 \text { days of receipt of } \\
\text { written notice from CCMA }\end{array}$ \\
\hline $\begin{array}{l}\text { 2.3 Criminal \& } \\
\text { Civil Charges }\end{array}$ & $\begin{array}{l}\text { Separate criminal \& } \\
\text { civil charges may be laid }\end{array}$ & $\begin{array}{l}\text { In severe cases and } \\
\text { for other infringement } \\
\text { of rights }\end{array}$ & $\begin{array}{l}\text { Rights of victim to take any other legal action, } \\
\text { such as approaching the police, or an attorney, } \\
\text { are not limited by the application of the above } \\
\text { code in the workplace }\end{array}$ \\
\hline
\end{tabular}

* irrelevant details of Labour Relations Act (1995) are not included here / CCMA: Commissioner for Conciliation, Mediation and Arbitration / Guidelines and Codes of Practice / GN 1367 of 198: Notice of code of good practice on the handling of sexual harassment cases. Labour Relations Act No 66 of 1995

tive process have been summarised in Table 2.

Once the investigative stage has been concluded and it has been decided that a formal disciplinary inquiry is to be held in the workplace, complete confidentiality or anonymity can no longer be guaranteed and the victim should be warned of this. However, the Guidelines and Codes of Practice (1998) and the Labour Relations Act (1995) state that the following information must still remain absolutely confidential:

1. Information which is legally privileged and which may not be made public according to a court order, or according to the law; 
Table 2: Guidelines according to which complaints of sexual harassment in a private physiotherapy practice may be investigated.

\begin{tabular}{|c|c|c|}
\hline \multicolumn{3}{|c|}{ GUIDELINES FOR INVESTIGATING SEXUAL HARASSMENT IN THE WORKPLACE } \\
\hline Procedures & Method & Additional precautions \\
\hline $\begin{array}{l}\text { Interview with } \\
\text { complainant }\end{array}$ & $\begin{array}{l}\text { Questions: Must understand the complaint \& implications / when \& } \\
\text { where did it occur / how long been going on / did the complainant } \\
\text { indicate it was unwelcome \& what was the offender's reaction to } \\
\text { this / why time-lag before reporting / any witnesses \& discussed with } \\
\text { them } 1 \text { / corroborating evidence - notes, letters etcetera } 1,2 \text { / who has } \\
\text { been told \& relationship to complainant / offender's words or actions / } \\
\text { context (such as a joke) / clothes of each party / relationship before } \\
\text { the time \& both parties' perceptions of relationship / social contact } \\
\text { beforehand - individually or as group / dating beforehand / how long } \\
\text { known each other / has offender done this to you before or to anyone } \\
\text { else / sexist atmosphere at work - such as explicit jokes / has } \\
\text { superior reacted to this atmosphere / also complained in the past } \\
\text { and reaction experienced / effect on job opportunities or promotion / } \\
\text { personal choice of resolving issue / need more help to cope } 2\end{array}$ & $\begin{array}{l}\text { Conduct original interview on own } \\
\text { with complainant as he / she } \\
\text { already feels vulnerable / take } \\
\text { notes; if a tape is used, inform the } \\
\text { complainant and state that it is a } \\
\text { more accurate reflection of what } \\
\text { has been said than notes } 1 \text { / } \\
\text { remind complainant that interview } \\
\text { or investigation does not preclude } \\
\text { him / her taking other legal action } 3\end{array}$ \\
\hline $\begin{array}{l}\text { Interview of } \\
\text { alleged offender }\end{array}$ & $\begin{array}{l}\text { Questions: Do you know the reason for the interview / what is your } \\
\text { version of the incident or story / what did each of you say / any } \\
\text { touching of the victim, where \& how \& why \& his / her reaction / } \\
\text { where \& when did it happen / what was each party wearing / any } \\
\text { witnesses / which part of allegation is true \& which is false / who } \\
\text { did you inform of this incident \& what is your relationship / does the } \\
\text { work atmosphere encourage sexist behaviour, such as explicit jokes / } \\
\text { did you try to alter this atmosphere / how did the complainant behave } \\
\text { previously and has he / she changed his / her behaviour recently \& } \\
\text { has this been seen by others / has he / she changed his / her } \\
\text { behaviour towards these types of incidents \& how did he / she react } \\
\text { before / how long have you known each other and type of previous } \\
\text { relationship / did you have any say in promotion or opportunities \& } \\
\text { if you did has complainant's performance been measured } \\
\text { objectively / what is the motivation for a false claim / do you have } \\
\text { any suggestions for resolving the situation } 2\end{array}$ & $\begin{array}{l}\text { Conduct it with the utmost } \\
\text { discretion to avoid legal suits of } \\
\text { slander or unjustifiable libel of } \\
\text { reputation } 1 / \text { innocent until proven } \\
\text { guilty } 1 / \text { inform alleged offender of } \\
\text { how the investigation will proceed } \\
\text { further / warn that no retaliation } \\
\text { may be directed towards } \\
\text { complainant }^{2,3}\end{array}$ \\
\hline $\begin{array}{l}\text { Interview of } \\
\text { witnesses }\end{array}$ & $\begin{array}{l}\text { Questions (possible witnesses): seen or heard anything unusual / } \\
\text { do all employees get along / is the atmosphere sexist, such as } \\
\text { explicit jokes } 1 \\
\text { Questions (definite witnesses): has complainant indicated before that } \\
\text { behaviour was offensive / who has he / she had problem with / what } \\
\text { kind of relationship did the two have -business, social, ever dated / } \\
\text { how long have they known each other / has he / she told anyone of } \\
\text { the incident / did superior know of problem and do anything about it / } \\
\text { what did you see or hear / who have you told of this incident / your } \\
\text { relationship with both parties \& superior } 2\end{array}$ & $\begin{array}{l}\text { 1) Possible witnesses: } \\
\text { Do not reveal names of } \\
\text { complainant or alleged offender / } \\
\text { pick words carefully to avoid } \\
\text { possible slander / ask general } \\
\text { questions only } 1 \\
\text { 2) Definite witnesses: warn not } \\
\text { to discuss the matter further } 2\end{array}$ \\
\hline $\begin{array}{l}\text { Collect all } \\
\text { documentation }\end{array}$ & $\begin{array}{l}\text { All papers used as proof, such as offender's objective evaluation of } \\
\text { complainant's work performance / previous documents of disciplinary } \\
\text { inquiries / Offender's written offensive notes or letters or other } \\
\text { material / All other written evidence }\end{array}$ & \\
\hline $\begin{array}{l}\text { Compile a } \\
\text { report }\end{array}$ & $\begin{array}{l}\text { Investigation inconclusive: } \\
\text { 1) inform complainant - can he / she still work there (if not, arrange } \\
\text { transfer) / remind him / her to report any future incidents }{ }^{1} \\
\text { 2) inform alleged offender: offer advice on correct behaviour / } \\
\text { remind that new incidents will be investigated with possibility of } \\
\text { dismissal if found guilty } 1 \\
\underline{\text { Investigation - guilty verdict: }} \\
\text { Make a recommendation }\end{array}$ & \\
\hline Recommendation & $\begin{array}{l}\text { Investigation - guilty verdict: Normally dismissable offence only if } \\
\text { severe or recurring } 4 \text { / give written warning } 1,4 \text { / examine offender's } \\
\text { circumstances, such as length of employment, personal circumstances, } \\
\text { previous disciplinary record, nature of job \& type of behaviour } 4\end{array}$ & $\begin{array}{l}\text { Discipline must be consistently the } \\
\text { same for all employees \& } \\
\text { consistent for same type of } \\
\text { harassment (infringement) } 4 \text { / }\end{array}$ \\
\hline
\end{tabular}




\begin{tabular}{|c|c|c|}
\hline Procedures & Method & Additional precautions \\
\hline & $\begin{array}{l}\text { Disciplinary hearing: To determine whether dismissable offence } \\
\text { Investigation - inconclusive or guilty verdict: } \\
\text { If work atmosphere was conducive to sexist behaviour, } \\
\text { educate \& warn employees about expected behaviour (suggestion } \\
\text { from this study) } \\
\text { Behaviour towards complainant if guilty verdict: } \\
\text { 1) What does he / she expect } \\
\text { 2) Rectify any unfairly-denied promotion } \\
\text { 3) Pay out any lost wages } \\
\text { 4) Offer job back if he / she transferred out of organisation } \\
\text { 5) If a settlement is reached, have it in writing, but first have both } \\
\text { parties' attorneys evaluate it }{ }^{1}\end{array}$ & $\begin{array}{l}\text { if disciplinary hearing to determine } \\
\text { dismissable offence - trade union } \\
\text { representative to be present, } \\
\text { complainant } \& \text { alleged offender, } \\
\text { management } \& \text { witnesses }{ }^{3} / \\
\text { both parties' identities to remain } \\
\text { confidential at formal disciplinary } \\
\text { hearing } 3 \text { / inform offender that the } \\
\text { CCMA may be approached if } \\
\text { discipline involves dismissal }{ }^{4}\end{array}$ \\
\hline
\end{tabular}

1. Lightle, J. \& Doucet, B. 1992, Sexual harassment in the workplace. A guide to prevention. Crisp Publications, Inc. California

2. Wagner, E.J. 1992, Sexual harassment in the workplace. How to prevent, investigate, and resolve problems in your organization, Amacom American Management Association, New York

3. Guidelines and Codes of Practice / GN 1367 of 1998: Notice of code of good practice on the handling of sexual harassment cases. Labour Relations Act No 66 of 1995 [Electronic], Available: http//:butteworths/butterworthslegal//pext.dll/BLLLib/BLL_LEG.nfo/4594/58cf/5c6b/5c [2002, Oct. 08]

4 Labour Relations Act (1995) Schedule 8 - Code of good practice: Dismissal, pp. 157-61, [Online], Avalable: http://www.polity.org.za/html/govdocs/ legislation/1999/act 95- 066html [2002, Nov. 25]

2. Where the divulging of confidential information may cause substantial harm to either the employee (alleged victim / perpetrator) or the employer;

3. Employee's (alleged victim or offender) private personal information, unless the relevant employee consents to its disclosure (Labour Relations Act 1995).

If there is any dispute about which information may be disclosed at the hearing, then any party may refer the dispute (in writing) to the Commission of Conciliation, Mediation and Arbitration (CCMA), who will handle the matter further according to their guidelines. The procedure of this formal disciplinary inquiry must conform to the regulations laid down by the Labour Relations Act (1995).

Since the South African Society of Physiotherapy (SASP), the body officially recognised as being representative of the physiotherapy profession in South Africa (South African Society of Physiotherapy 2004), is not a legitimate registered trade union (Workinfo 2003) - unlike the South African Medical Association (SAMA) (South African Medical Association 2004) - it does not represent individual members in workplace grievances. This would include any formal disciplinary inquiry into sexual harassment in the workplace. Furthermore, if the disciplinary inquiry is unresolved and the matter is referred to the CCMA, the Labour Relations Act (1995) allows unions to represent their members at an initial hearing of a disputed complaint, but lawyers may not represent nonunionised workers (Kumalo 1998). Although other workers employed in the same organisation as physiotherapists may therefore be represented by their unions at various levels involving a sexual harassment complaint, the physiotherapist has no-one to represent him / her. After the Commissioner of the CCMA has made a ruling that the conciliation process was unsuccessful, lawyers may then represent their clients at the following stage of the procedure, namely at the meeting held for arbitration (Shiburi 2004). It is only at this stage that a lawyer may accompany the physiotherapist to the hearing. Although lawyers from the Legal Aid Board may represent workers who cannot afford to hire legal representation, they do not get involved in sexual harassment issues (Kumalo 1998). The insurance taken out by the SASP on behalf of its members, is for payment of malpractice suits and associated legal representation only (Prinsloo and Kahn 2002). The physiotherapist, therefore, who cannot afford to pay for legal representation has no official, such as a union representative, or a lawyer, to represent him / her in any sexual harassment issues.

As in any other employment sector, the fear of victimisation (by the relevant institution, employer(s) or other employees) in the physiotherapy work environment may result in under-reporting of sexual harassment by a colleague, another healthcare professional or an employer. Although the recently promulgated Protected Disclosures Act (2000) is mainly targeted at protecting whistle-blowers who are aware of criminal or other irregular conduct of other people in the workplace, it also specifically protects those who would like to report unfair discrimination, which, as discussed previously, may also include sexual harassment. Figure 1 represents a summary of the guidelines to handling a complaint of sexual harassment in the workplace.

\section{Judicial court redress for victims of sexual harassment in South Africa}

Although the Guidelines and Codes of practice (1998) sets out clear guidelines (Table 1) of how grievances, which would include those related to sexual harassment, must be handled within the workplace environment itself, the victim may also resort to other means of seeking legal redress outside the work environment.

Sexual violence, such as rape, attempted rape and assault, which are the extreme forms of sexual harassment, clearly resort under criminal law, irrespective of whether they are perpetrated by healthcare professionals or not. The legal process in the court itself might be particularly emotionally harassing for the complainant (Kumalo 1998). In a criminal trial, the court must be satisfied that the defendant is guilty 'beyond a reasonable doubt', which sets a high standard for proof of guilt. 
Since sexual harassment on its own is not regarded as a criminal offence, the complainant may resort to the civil court for redress, where a lower burden of proof is required. Only a balance of probabilities is necessary to prove guilt in this instance. The type of charges laid against the offender could include damages for a wrongful and intentional (Kumalo 1998), or a wrongful and negligent act, which breaches body / physical integrity, personal dignity or reputation. However, a civil suit is far more financially draining than a criminal procedure, where the state carries the financial burden.

In contrast to a criminal procedure, the company / employer as well as the sexual harasser may be sued in a civil suit. Vicarious liability is an important legal concept in that the employer becomes responsible for the actions of its / his / her employee. Therefore, if there is a suspicion that an employee may be harassing someone and the employer does not react to this, or no clear guidelines have been given to the employee on how he or she should behave appropriately in specific circumstances (Guidelines and Codes of Practice 1998), the employer may be sued in a civil suit.

The employer may also be sued on the basis of 'constructive dismissal' if he / she did not react appropriately to the complaints of sexual harassment and the employee was forced to resign (Grogan 2001). The definition of constructive dismissal is 'Because the employer has broken fundamental terms of the contract of employment, the employee has been forced to resign' (Plain English Campaign 2002).

Furthermore, where an employer has exercised discrimination, including that pertaining to sexual harassment, such as ignoring relevant complaints, turning a blind eye to an overtly hostile environment or not informing employees of the appropriate conduct that is expected of them (Employment Equity Act 1998, Guidelines and Codes of Practice 1998, Labour Relations Act 1995), the victim may approach an Equality Court for redress with a 'prima facie' case of employer discrimination. The employer then has the burden of proving that his / her actions (or omissions) have not been discriminatory once a complaint of discrimination has been lodged with him / her.

Figure 1: Summary of guidelines (Tables 1 and 2) for management of sexual harassment in the workplace.

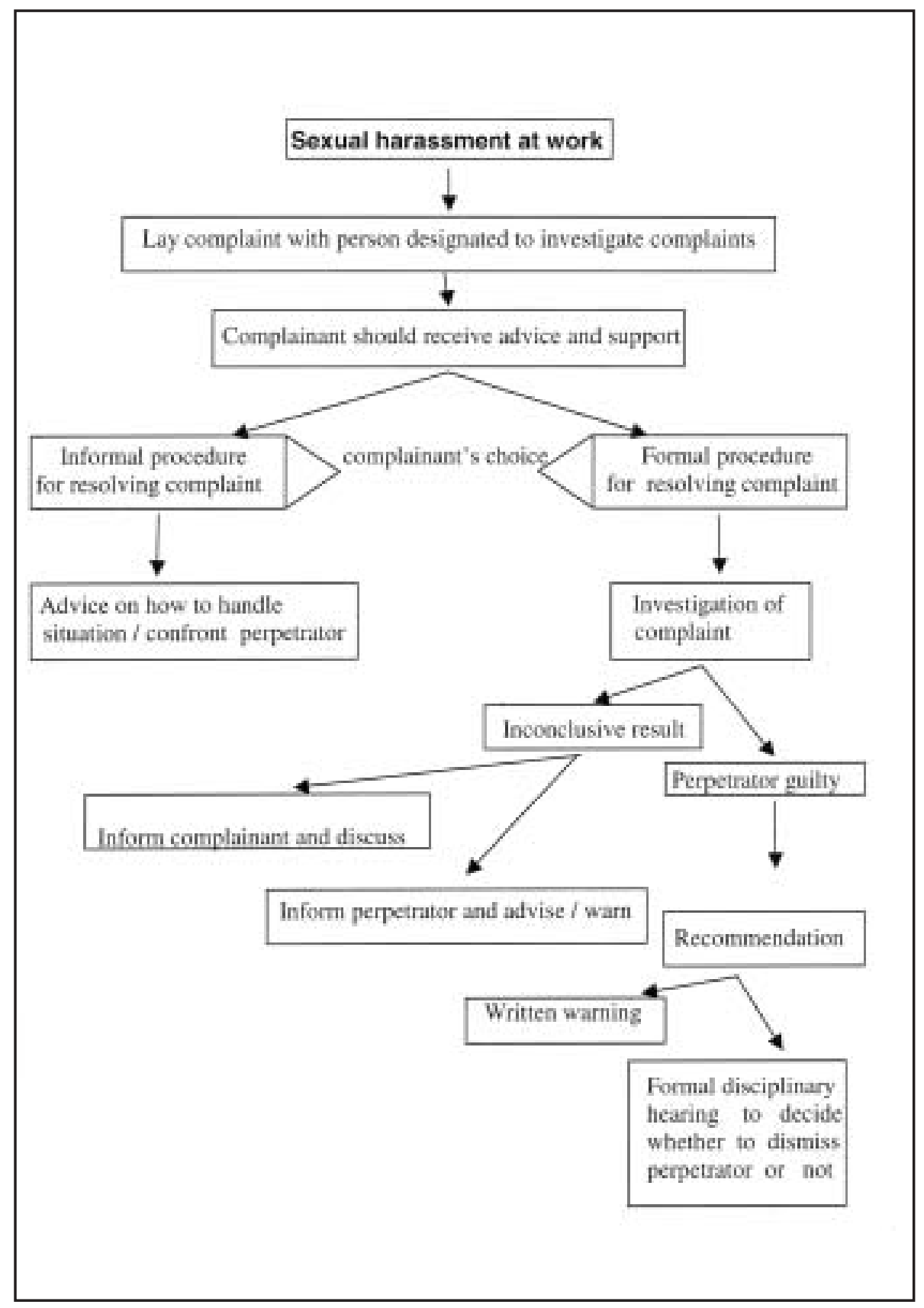

Financial assistance will be provided to the victims who lodge these complaints (Promotion of Equality and Prevention of Discrimination Act 2000). Figure 2 represents a schematic summary of the various legal options available for the physiotherapist who has been sexually harassed in the workplace.

\section{The Constitutional right to be free from sexual harassment}

Physiotherapists require more knowledge on the legal issues pertaining to sexual harassment (deMayo 1997, McComas et al 1993 and 1995, O'Sullivan and Weerakoon 1999, Weerakoon and O'Sullivan 1998). In South Africa, the Constitution is the supreme law of the land, and all laws and conduct must be consistent with it
(The Constitution of the Republic of South Africa 1996). Any information on sexual harassment should therefore refer to the general rights of every South African citizen, including that of the physiotherapist, to human dignity, equality and freedom, freedom and security of the person, including the right to be free of violence and body and psychological integrity, security and control over one's body, and to an environment not harmful to one's health (The Constitution of the Republic of South Africa 1996). Although SAMA (South African Medical Association 2002) has compiled a document for its members reflecting these principles, the SASP has not compiled a similar document for physiotherapists. 


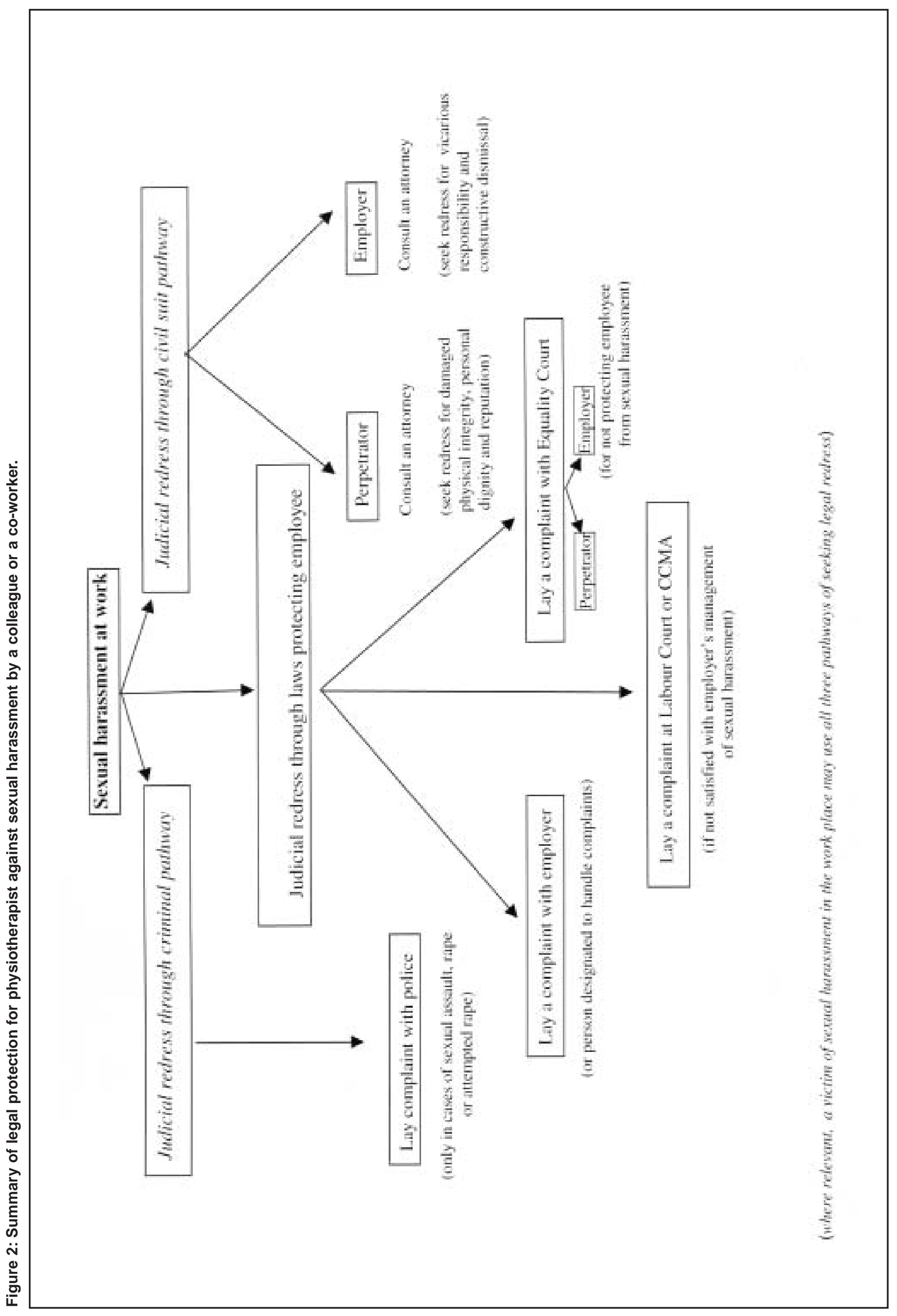




\section{CONCLUSION}

This paper on the legal framework pertaining to sexual harassment in the work environment in South Africa, which would include the physiotherapy work environment, supplies detailed information on how sexual harassment may be managed, even by individual private physiotherapy practices. Investigations into complaints of sexual harassment in the workplace are both time-consuming and a harrowing experience for all parties involved. It is therefore recommended that sexual harassment in the workplace should rather be avoided than investigated and handled.

\section{REFERENCES}

Barnett KH 1996 Reporting sexual harassment in an undergraduate nursing program. Nurse Education 21: 3-4

Bronner G, Peretz C, Ehrenfeld M 2003 Sexual harassment of nurses and nursing students. Journal of Advanced Nursing 42: 637-648

Cedaw-Convention on the elimination of all forms of discrimination against women. Part I nd [Online] Available: http://www.un.org./ womenwatch/daw/cedaw/part1.htm [2002, Sept. 8]

Code of Good Practice on Key Aspects of Disability in the Workplace 2001 (Employment Equity Act No 55 of 1998) / GN No 7047. Government Gazette (No 22209): 3-19

Cook DJ, Griffith LE, Cohen M, Guyatt GH, O'Brien B 1995 Discrimination and abuse experienced by general internists in Canada. Journal of Internal Medicine 10: 563-572

Dental Protection Ltd 1998/99 Dental Protection annual review: Case Histories Complaint? Go somewhere else! Medical Protection Society Ltd, London 10: 35

DeMayo RA 1997 Patient sexual behaviors and sexual harassment: a national survey of physical therapists. Physical Therapy 77: 739-744

Employment Equity Act No 55 of 1998 [Online] Available: http://www.info.gov.za/ acts/1998a55-98.pdf [2004, Jun.04]

Finnis SJ, Robbins I 1994 Sexual harassment of nurses: an occupational hazard. Journal of Clinical Nursing 3: 87-95

Grogan J 2001 Workplace Law, 6th edn. pp 148-150. Juta Law, South Africa

Guidelines and Codes of Practice / GN 1367 of 1998 Notice of code of good practice on the handling of sexual harassment cases. Labour Relations Act 66 of 1995 [Electronic] Available:http://butterworths/butterworthslegal/ lpext.dll/BLLLib/BLLL_LEG.nfo/4594/58cf/ $5 \mathrm{c} 6 \mathrm{~b} / 5 \mathrm{c}$ [2002, Oct.08]

Hanrahan PM 1995 The social construction of sexual harassment in nursing. University of Massachusetts, $\mathrm{PhD}$ dissertation
Human Rights Watch 2001 South Africa's obligations under International and National Law. [Online] Available: http://www.hrw.org/ reports/2001/safrica/ZA-FINAL-09.htm [2002, Jun.20]

International Labour Organization 2001 Employment Equity Act No 55 of 1998 [Online] Available: http://www.ilo.org/public/ english/employment/gems/eeo/.../eea.ht [2002, Jun.20]

Koba H 1995 U of T medical school uses multiple strategy to prevent sexual harassment. Canadian Medical Association Journal 152: $414-415$

Kumalo P 1998 Sexual Harassment? It's a No-Go Area. [Electronic] Available: http: //womensnet. Org.za/pvaw/laws/sexharas.htm [2002, Aug.17]

Labour Relations Act No 66 of 1995 [Online] Available: http://www.polity. org.za/ html/govdocs/ legislation/1995/act95-066html [2002, Nov.25]

Libbus MK, Bowman KG 1994 Sexual harassment of female registered nurses in hospitals. Journal of Nursing Administration 24: 26-31

Lightle J, Doucet B 1992 Sexual harassment in the workplace. A guide to prevention, $\mathrm{pp} 29$, 75, 77-80, 82. Crisp Publishers Inc, California

Madison J 1997 RNs' experiences of sex-based and sexual harassment - an empirical study. Australian Journal of Advanced Nursing 14: 29-37

Maida AM, Vasquez A, Herskovic V Calderon JL, Jacard M, Pereira A, Widdel L 2003 A report on student abuse during medical training. Medical Teacher 25: 497-501

Margittai KJ, Moscarello R, Rossi MF 1996 Forensic aspects of medical student abuse: a Canadian perspective. Bulletin of the American Academy of Psychiatry \& the Law 24: 377-385

McComas J, Herbert C, Giacomin C, Kaplan, D Dulberg C 1993 Experiences of student and praticing physical therapists with inappropriate patient sexual behaviour. Physical Therapy 73: 762-770

McNamara RM, Whitley TW, Sanders AB, Andrew LB 1995 The extent and effects of abuse and harassment of emergency medicine residents. The SAEM In-service Survey Task Force. Academic Emergency Medicine 2: 293-301

Moscarello R, Margittai KJ, Rossi MF 1996 Impact of faculty education on the incidence of sexual harassment experienced by Canadian medical students. Journal of Women's Health 5: 231-237

Oancia T, Bohm C, Carry T, Cujec B, Johnson D 2000 The influence of gender and specialty on reporting of abusive and discriminatory behaviour by medical students, residents and physician teachers. Medical Education 34: 250-256
O’Sullivan V, Weerakoon P 1999 Inappropriate sexual behaviours of patients towards practicing physiotherapists: a study using qualitative methods. Physiotherapy Research International 4: 28-41

Plain English Campaign 2002 Issues and subjects: Law [Online] Available: http://www.plainenglish.co.uk/legalaz.html [2002, Jul. 24]

Prinsloo R, Khan S 2002 What's up in the mail: Lack of legal representation (Letter and Reply). PhysioForum Oct: 18

Promotion of Equality and Prevention of Unfair Discrimination Act No 4 of 2000 Government Gazette (No 20876) 416, Cape Town

Protected Disclosures Act No 26 of 2000 [Online] Available: http://www.open democracy.org.zaprotected $\% 20$ disclosures \%20act.pdf [2004, Jan.19]

Robbins I, Bender MP, Finnis SJ 1997 Sexual harassment in nursing. Journal of Advanced Nursing 25: 163-169

Seminars tackle sexual harassment in the workplace 1998 Monday Paper 17 [Online] Available:http://www.uct.ac.za/depts/dpa/ monpaper/98-no22/agi.htm [2002, Oct.7]

Shiburi W 2004 Labour Official. Department of Labour (Pretoria), Conversation with the author

South African Medical Association 2002 Report by Human Rights, Law and Ethics Committee: Doctors' and Patients' Rights and Responsibilities. SAMA Publication, Pretoria.

South African Medical Association 2004 Membership benefits. [Online] Available: http://www.samedical.org [2004, Jan.15]

South African Society of Physiotherapy (Peer Review Committee) 2002 Do you know who to turn to? PhysioForum July: 17

South African Society of Physiotherapy 2004 SASP Membership. [Online] Available: http://www.physio.org.za/frame.asp.page $=$ membership/membership.asp [2004, Jan.15]

The Constitution of the Republic of South Africa 1996 Government Gazette (No 17678) 378: Chapter 2: 7-20, Cape Town

Uhari M, Kokkonen J, Nuutinen M, Vainonpaa L, Rantala H, Lautala P, Vayrynen M 1994 Medical student abuse: an international phenomenon. Journal of the American Medical Association 271: 1049-1051

Wagner EJ 1992 Sexual harassment in the workplace. How to prevent, investigate, and resolve problems in your organization. Appendix A, pp 133-138. Amacom American Management Association, New York

Weerakoon P, O’Sullivan V 1998 Inappropriate Patient Sexual Behaviour in Physiotherapy Practice. Physiotherapy 84: 491-499

Workinfo 2003 List of Registered Trade Unions. [Online] Available: http://www. workinfo.com/free/sub_for_legres/data/lra/ union.htm [2004, Jan.15] 